\title{
Papel da Lidocaína por Via Venosa no Tratamento da Dor na Esclerodermia. Relato de Caso *
}

\author{
Intravenous Lidocaine to Treat Scleroderma Pain. Case Report
}

Durval Campos Kraychete, TSA ${ }^{1}$; Ana Cristina Guimarães ${ }^{2}$; Maria Goreth Carvalho ${ }^{2}$; Edgar Marcelino de Carvalho ${ }^{3}$

\begin{abstract}
RESUMO
Kraychete DC, Guimarães AC, Carvalho MG, Carvalho EM - Papel da Lidocaína por Via Venosa no Tratamento da Dor na Esclerodermia. Relato de Caso
\end{abstract}

JUSTIFICATIVA E OBJETIVOS: A esclerodermia ou esclerose sistêmica progressiva é uma doença sistêmica do tecido conjuntivo, de causa desconhecida, que costuma cursar com microangiopatia, isquemia de extremidades e dor intensa. $O$ objetivo deste relato é descrever um caso do emprego de lidocaína por via venosa no tratamento da dor no curso de isquemia e enfatizar a possível ação antiinflamatória dos anestésicos locais nos pacientes com esclerodermia.

RELATO DO CASO: Paciente do sexo feminino, 34 anos, auxiliar de enfermagem, portadora de esclerodermia há aproximadamente 8 anos, apresentava dor de elevada intensidade (escala numérica $=10$ ) nos membros superiores e inferiores, contínua, diária, acompanhada de alterações tróficas, da cor e da temperatura e pequenas úlceras nas extremidades. A paciente foi submetida a uma sessão semanal de lidocaína a $2 \%(400 \mathrm{mg}) \mathrm{sem}$ vasoconstritor por via venosa durante 10 semanas com alívio da dor, do turgor, da elasticidade da pele e da perfusão periférica.

CONCLUSÕES: O alívio da dor e de outros sintomas após a administração de lidocaína por via venosa sugere que os anestésicos locais podem modular a resposta inflamatória em vários estágios da esclerodermia.

Unitermos: ANESTÉSICOS, Local: lidocaína; DOENÇAS: esclerodermia; DOR, Crônica

\author{
SUMMARY \\ Kraychete DC, Guimarães AC, Carvalho MG, Carvalho EM - \\ Intravenous Lidocaine to Treat Scleroderma Pain. Case Report
}

BACKGROUND AND OBJECTIVES: Scleroderma or progressive systemic sclerosis is a systemic connective tissue disease of unknown origin, which normally courses with microangiopathy, extremities ischemia and severe pain. This report aimed at describing a case of intravenous lidocaine to treat ischemic pain and at emphasizing potential anti-inflammatory action of local anesthetics in scleroderma patients.

CASE REPORT: Female patient, clear mulatto 34 years old, nursing assistant, with scleroderma for approximately 8 years, presented with severe continuous, daily pain (numeric scale = 10) in upper and lower limbs, followed by trophic, color and temperature changes, and small ulcers on extremities. Patient was submitted to 1 weekly session of intravenous $2 \%$ lidocaine $(400$ $\mathrm{mg}$ ) without vasoconstrictor for 10 weeks with pain, turgor, skin elasticity and peripheral perfusion improvement.

CONCLUSIONS: Pain and other symptoms relief after intravenous lidocaine suggests that local anesthetics are able to modulate inflammatory response in different scleroderma stages.

Key Words: ANESTHETICS, Local: lidocaine; DISEASES: scleroderma; PAIN, Chronic

\section{INTRODUÇÃO}

A esclerose sistêmica progressiva ou esclerodermia é uma doença do tecido conjuntivo, caracterizada pelo acúmulo de colágeno na pele, subcutâneo, músculos, sinóvia, artérias e órgãos internos, causando alterações vasculares (microangiopatia), degenerativas e fibróticas;

\footnotetext{
* Recebido do (Received from) Ambulatório de Dor - Hospital Universitário Professor Edgar Santos da Universidade Federal da Bahia (UFBA) Salvador, BA

1. Professor Assistente de Anestesiologia da UFBA. Coordenador do Ambulatório de Dor da UFBA e do Curso de Pós-Graduação em Clínica de Dor da UNIFACS.

2. Médica Supervisora do Ambulatório de Dor - UFBA

3. Professor Titular do Serviço de Imunologia - UFBA
}

Apresentado (Submitted) em 11 de fevereiro de 2003

Aceito (Accepted) para publicação em 22 de abril de 2003

Endereço para correspondência (Correspondence to)

Dr. Durval Campos Kraychete

Av. Euclides da Cunha, 610/902 Graça

40150-121 Salvador, BA

E-mail: dkt@terra.com.br

(c) Sociedade Brasileira de Anestesiologia, 2003

Revista Brasileira de Anestesiologia

Vol. 53, N 6, Novembro - Dezembro, 2003 aumento da espessura da pele e do tecido celular subcutâneo. A esclerodermia apresenta incidência rara, variando de 2 a 10 em cada 1 milhão de pessoas, com maior prevalência no sexo feminino ${ }^{1,2}$.

A microangiopatia da esclerodermia decorre da hiperplasia da íntima, da reação inflamatória de todas as camadas da parede do vaso, da trombose da adventícia e da teleangiectasia da vasa vasorum, provocando, então, estreitamento e obstrução dos vasos. A microangiopatia também é responsável pelo fenômeno de Raynaud que ocorre em $95 \%$ dos casos, sendo mais freqüente entre as mulheres $(85 \%)^{2}$. Este fenômeno caracteriza-se pela alteração de cor das extremidades (azul, vermelha ou pálida) à exposição ao frio ou ao calor. Devido ao comprometimento vascular, podem ocorrer áreas de necrose e ulcerações acometendo, principalmente, as mãos e os pés ${ }^{3}$. O tratamento da esclerodermia é direcionado, por tratar-se de uma doença de causa desconhecida, para meIhorar a circulação sangüínea periférica (vasodilatadores e antiagregantes plaquetários), prevenir a síntese e a liberação de citocinas (drogas imunossupressoras) e inibir ou reduzir a fibrose (agentes que reduzem a síntese de colágeno ou aumentam a produção de colagenase) ${ }^{4}$. 
Neste relato é mostrada a resposta analgésica da lidocaína por via venosa em paciente portadora de microangiopatia esclerodérmica. Também, são discutidas as possíveis propriedades antiinflamatórias dessa droga, indicando a necessidade de desenvolvimento de novos estudos clínicos e experimentais.

\section{RELATO DO CASO}

Paciente do sexo feminino, 34 anos, auxiliar de enfermagem, portadora de esclerodermia há aproximadamente 8 anos. Vinha cursando com quadro de síndrome de Raynaud há 3 anos e alterações isquêmicas nas extremidades das mãos e dos pés, razão de amputações parciais de algumas falanges. Na primeira consulta no Ambulatório de Dor - UFBA, apresentava dor de elevada intensidade (escala numérica $=10$ ) nos membros superiores e inferiores, contínua, diária, acompanhada de alterações tróficas, da cor e da temperatura, e pequenas úlceras nas extremidades. Havia relato de acidente vascular cerebral isquêmico, sem seqüelas neurológicas e fibrose pulmonar. A paciente vinha em tratamento com reumatologista, fazendo uso de pulsos de corticosteróide (metilprednisona - $1 \mathrm{~g} /$ dia por 3 dias) e imunossupressor (ciiclofosfamida-0,5 grama por metro quadrado), sem apresentar meIhora da dor e da cianose. Foi submetida a uma sessão semanal de lidocaína a $2 \%$ sem vasoconstritor em solução de 400 mg diluída em $500 \mathrm{ml}$ de solução fisiológica a 0,9\%, com infusão de $260 \mathrm{ml} . \mathrm{h}^{-1}$, durante 10 semanas. Observou-se alívio acentuado da dor (escala numérica $=4$ ) por um período de 4 a 5 dias que se seguia ao procedimento e, após o término do tratamento, houve melhora do turgor, da elasticidade da pele e da perfusão periférica. A paciente não apresentou qualquer complicação referente ao uso do anestésico local.

\section{DISCUSSÃO}

Na esclerodermia, a dor associada ao fenômeno de Raynaud é causada pela microangiopatia periférica e pela neuropatia isquêmica. Dentre as alterações histológicas encontradas na microangiopatia, evidencia-se a reação inflamatória, que afeta todas as camadas da parede vascular, gerando redução do fluxo sangüíneo na musculatura dos membros, acidose tissular, que associada à hipoxemia ativam nociceptores. O baixo fluxo sangüíneo na vasa nervorum leva à desmielinização do nervo, com subseqüente atividade espontânea da fibra. Isso é interpretado como dor em queimação, geralmente intensa e acompanhada de hiperestesia ou analgesia do dermátomo correspondente ${ }^{1,5}$. A literatura, contudo, ainda não evidenciou um método efetivo para o tratamento a longo prazo da dor e da microangiopatia das extremidades na esclerodermia. O emprego da nifedipina como droga padrão foi um equívoco ${ }^{6}$. Outras técnicas utilizadas como a simpatectomia cirúrgica ou química (anestésicos locais ou química) 2,7 , estimulação do corno dorsal posterior da medula espinhal 8 , não foram eficazes. Por outro lado, apesar da associação de opióide e anestésico local por via espinhal acarretar alívio satisfatório da dor, esse método não é conveniente para tera- pia prolongada, devido a fibrose peridural, oclusão e perda do cateter, dor local recorrente e infecção ${ }^{9}$.

Os anestésicos locais possuem ações anestésicas e antiarrítmicas bem estabelecidas, reconhecida capacidade de bloquear os canais de sódio, além de outros efeitos em sistemas celulares. É evidente a redução da descarga neuronal ectópica e o emprego dessas drogas no tratamento da dor neuropática ${ }^{10}$. Uma das atuações mais promissoras, entretanto, está relacionada à resposta inflamatória, interferindo nos macrófagos, monócitos e, sobretudo, nos polimorfonucleares ${ }^{11}$. Isso tem sido testado em vários estudos clínicos e em animais de experimentação, tais como na: (1) lesão pulmonar pós-aspiração de conteúdo ácido ${ }^{12}$; (2) sepse ${ }^{12,13}$; (3) obstrução de íleo ou peritonite ${ }^{14,15} ;$ (4) colite ulcerativa ${ }^{14,16}$. O tratamento com anestésicos locais tem melhorado o prognóstico dessas diversas condições em que o processo inflamatório está implicado na fisiopatologia da doença. Desse modo, os anestésicos locais podem agir sobre os polimorfonucleares e macrofágos, inibindo a liberação de citocinas, leucotrienos, histamina e prostaglandinas e com isso reduzir a permeabilidade vascular, a secreção de fluidos e o extravasamento de colóides. Também, ocorre diminuição da adesividade, motilidade e migração dos polimorfonucleares para o local da lesão e aumento da produção e liberação de óxido nítrico, radicais livres e enzimas lisossomiais ${ }^{14,17,18}$. A maioria dos receptores envolvidos no processo inflamatório pertence à classe de receptores acoplados à proteína G. Os anestésicos locais parecem inibir a tradução de sinal após ativação de vários desses receptores, modulando a resposta inflamatória, bem como a resposta neurovegetativa simpática. Há relato, ainda, da interação dos anestésicos locais com receptores muscarínicos ${ }^{1,14}$.

Baseado na hipótese de que os anestésicos locais podem interferir no processo inflamatório causado pela esclerodermia, optou-se, então, pela lidocaína por via venosa, por tratar-se de comprometimento vascular dos membros superiores e inferiores. A concentração sangüínea de anestésicos locais alcançada difere amplamente entre os indivíduos, na dependência do método de aplicação. Alguns autores sugerem concentração alvo-controlada entre 1 e $3 \mu \mathrm{g} \cdot \mathrm{ml}^{-1}$ em 20 minutos; contudo, isso requer tecnologia avançada e não foi possível realizar no serviço. A dose utilizada nessa paciente foi baseada na dose média de lidocaína administrada nesses estudos que foi de $488 \pm 98 \mathrm{mg}$, com níveis séricos de 2,94 \pm $0,31 \mathrm{mg}$, embora efeitos colaterais indesejáveis possam acontecer na faixa de 1,56 $\pm 0,61 \mu \mathrm{g} \cdot \mathrm{ml}^{-1}{ }^{19}$. Nesse relato, houve analgesia prolongada, sem efeitos colaterais e com redução das alterações isquêmicas. Outros estudos clínicos evidenciaram analgesia com 2 mg. $\mathrm{kg}^{-1}$ (administrado em 1 hora) de lidocaína e constataram que não há uma relação linear entre as concentrações plasmáticas ou no líquor da droga e o início ou a duração da analgesia ${ }^{20}$. Por outro lado, não existe um consenso na literatura quanto a dose sérica necessária para efeito antiinflamatório e os trabalhos referem doses semelhantes à analgésica ${ }^{21}$.

Pode-se concluir que os mecanismos celulares em que os anestésicos locais exercem a ação antiinflamatória são pou- 
co compreendidos. Os modelos clínicos e experimentais utilizados na literatura possuem resultados conflitantes. Os anestésicos locais, contudo, possuem um potencial clínico que pode ser significativo no alívio da dor em doenças de natureza imune e inflamatória. Isso requer investigações futuras e desenvolvimento de estudos do tipo I (prospectivos, aleatórios e placebo controlado).

\section{Intravenous Lidocaine to Treat Scleroderma Pain. Case Report}

Durval Campos Kraychete, TSA, M.D.; Ana Cristina Guimarães, M.D.; Maria Goreth Carvalho, M.D.; Edgar Marcelino de Carvalho, M.D.

\section{INTRODUCTION}

Progressive systemic sclerosis, or scleroderma, is a connective tissue disease characterized by skin, subcutaneous, muscles, synovia, arteries and internal organs collagen build up, determining vascular (microangiopathy), degenerative and fibrotic changes, skin and subcutaneous cellular tissues thickening. Scleroderma is rare, with an incidence of 2 to 10 out of 1 million people, being more prevalent in females ${ }^{1,2}$.

Sclerodermic microangiopathy is a consequence of intima hyperplasia, inflammatory reaction of all vessel wall layers, adventitia thrombosis and vasa vasorum telangiectasis, thus leading to vessels narrowing and obstruction. Microangiopathy is also responsible for the Raynaud phenomenon, present in $95 \%$ of cases and being more frequent in women $(85 \%)^{2}$. This phenomenon is characterized by changes in extremities color (blue, red or pale) when exposed to cold or heat. Due to vascular involvement, there may be areas of necrosis and ulcerations especially affecting hands and feet ${ }^{3}$. For being a disease of unknown origin, scleroderma treatment is directed toward improving peripheral blood flow (vasodilators and anti-platelet drugs), preventing cytokines synthesis and release (immunosuppressant drugs), and inhibiting or decreasing fibrosis (agents decreasing collagen synthesis or increasing colagenase production) ${ }^{4}$. This report aimed at describing intravenous lidocaine analgesic response in sclerodermic microangiopathy patient. Potential anti-inflammatory properties of this drug are also discussed, indicating the need for further clinical and experimental trials.

\section{CASE REPORT}

Female patient, 34 years old, nursing assistant, with scleroderma for approximately 8 years, together with Raynaud syndrome for 3 years and ischemic changes on hands and feet, which had led to partial amputation of some phalanges. When she first presented to the Pain Outpatient
Clinic - UFBA, she referred upper and lower limbs severe, continuous and daily pain (numeric scale $=10$ ) followed by trophic, color and temperature changes and small ulcers on the extremities. Patient has a history of ischemic stroke without neurological sequelae and pulmonary fibrosis. Patient was being treated by a rheumatologist with steroid pulses (methylpredisone - $1 \mathrm{~g} / \mathrm{day}$ for 3 days) and immunosuppressants (cyclophosphamide - $0.5 \mathrm{gram} / \mathrm{m}^{2}$ ), without pain and cyanosis improvement. Patient was submitted to 1 weekly session of $2 \%$ lidocaine without vasoconstrictor in $400 \mathrm{mg}$ solution diluted in $500 \mathrm{ml}$ of $0.9 \%$ saline and infusion of $260 \mathrm{ml}^{-\mathrm{h}^{-1}}$ for 10 weeks. There has been significant pain relief (numeric scale $=4$ ) during 4 or 5 days after the procedure and, after treatment, there has been improvement in turgor, skin elasticity and peripheral perfusion. There were no complications related to local anesthetic administration.

\section{DISCUSSION}

In scleroderma, pain associated to Raynaud phenomenon is determined by peripheral microangiopathy and ischemic neuropathy. Among histological microangiopathic changes, one may mention inflammatory reaction affecting all vascular wall layers, determining blood flow decrease in limb muscles, and tissue acidosis, which activate nociceptors when associated to hypoxemia. Low vasa nervorum blood flow leads to nerve demyelinization with subsequent spontaneous fiber activity. This is interpreted as burning pain, in general severe and followed by corresponding dermatome hyperstesia or analgesia $^{1,5}$. Literature, however, has not yet identified an effective method for the long-term management of pain and extremities microangiopathy during scleroderma. Nifedipine as the standard drug was a mistake ${ }^{6}$. Other techniques, such as surgical or chemical sympathectomy (local anesthetics or chemicals) $)^{2,7}$ and spinal cord posterior dorsal horn stimulation ${ }^{8}$ were ineffective. On the other hand, although the association of spinal opioids and local anesthetics determines satisfactory pain relief, this method is not convenient for prolonged therapy due to epidural fibrosis, catheter occlusion or loss, recurrent local pain and infection ${ }^{9}$.

Local anesthetics have well-established anesthetic and anti-arrhythmic actions, proven ability to block sodium channels, in addition to other effects in cell systems. Ectopic neuronal discharge decrease and the use of such drugs to treat neuropathic pain are unquestionable ${ }^{10}$. One of the most promising actions, however, is related to inflammatory response, interfering with macrophages, monocytes and, mostly with polymorphonuclears ${ }^{11}$. This has been tested in several clinical and animal trials, such as in 1) pulmonary injury after acid content aspiration ${ }^{12} ; 2$ ) sepsis ${ }^{12,13} ; 3$ ) ileum obstruction or peritonitis $\left.{ }^{14,15}, 4\right)$ ulcerative coliltis ${ }^{14,16}$. Treatment with local anesthetics has improved the prognosis of these conditions in which an inflammatory process is implied. This way, local anesthetics may act on polymorphonuclears and macrophages, inhibiting cytokines, leucotriens, histamine and prostaglandin release, thus decreasing vascular 
patency, fluid secretion and colloid leakage. There is also a decrease in polimorphonuclear adhesion, motility and migration to the injury site and increase in nitric oxide, free radicals and liposomal enzymes production and release ${ }^{14,17,18}$. Most receptors involved in the inflammatory process belong to the class of receptors bound to $G$ protein. Local anesthetics seem to inhibit signal translation after the activation of several receptors, modulating inflammatory response as well as sympathetic neurovegetative response. There is also a report on the interaction of local anesthetics with muscarinic receptors ${ }^{1,14}$

Based on the hypothesis that local anesthetics may interfere with scleroderma-induced inflammatory process, we decided for intravenous lidocaine due to the vascular involvement of upper and lower limbs. Local anesthetic blood concentrations obtained vary among individuals and according to the administration method. Some authors suggest target-controlled concentrations between 1 and $3 \mu \mathrm{g} \cdot \mathrm{ml}^{-1}$ in 20 minutes; this however requires advanced technology and was impossible to perform in our department. The dose used in this patient was based on the mean lidocaine dose used in those trials, that is, $488 \pm 98 \mathrm{mg}$, with serum levels of $2.94 \pm$ $0.31 \mathrm{mg}$, although undesirable side-effects may be present in the range of $1.56 \pm 0.61 \mu \mathrm{g} \cdot \mathrm{ml}^{-1}{ }^{19}$. In our report, there has been prolonged analgesia, without side-effects and decreasing ischemic changes. Other clinical trials have evidenced analgesia with $2 \mathrm{mg} \cdot \mathrm{kg}^{-1}$ lidocaine (administered in 1 hour) and have observed no linear correlation between plasma or CSF concentrations of the drug and analgesia onset or duration $^{20}$. On the other hand, there is no consensus in the literature about the serum dose needed for anti-inflammatory effects and reports refer doses similar to analgesic doses ${ }^{21}$. One may conclude that cell mechanisms on which local anesthetics have anti-inflammatory action are still not well understood. Clinical and experimental models published in the literature present conflicting data. Local anesthetics, however, have a clinical potential which may be significant for pain relief in immune and inflammatory diseases. This requires further investigations and type I studies (prospective, randomized and placebo-controlled).

\section{REFERÊNCIAS - REFERENCES}

01. Lundborg C, Nitescu P, Appelgren L et al - Progressive systemic sclerosis: intrathecal pain management. Reg Anesth Pain Med, 1999;24:89-93.

02. Ward WA, Van Morre, Charlotte NC - Management of finger ulcers in scleroderma. J Hand Surg, 1995;20:868-872.

03. Vayssairat $M$ - Les phénomènes de Raynaud avec troubles trophiques. J Mal Vasc, 1992;17:127-131.

04. Sapadin NA, Fleischmajer R - Treatment of scleroderma. Arch Dermatol, 2002;138:99-105

05. Di Trapani G, Tulli A, La Cara A et al - Peripheral neuropathy in course of progressive systemic sclerosis. Light and ultrastructural study. Acta Neuropathol, 1986;72:103-110.

06. Leighton C - Drug treatment of scleroderma. Drugs, 2001;61: 419-427.
07. Biasi G, Giordanengo F, Pignoli P et al - 25 ani di esperienza nel trattamento della malattia di Raynaud e delle sindromi Raynaud-simili. Minerva Chir, 1980;35:663-667.

08. Broggi G, Servello D, Franzini A et al - Epidural stimulation for peripheral vascular disease: 10 years of experience. Ital $\mathrm{J}$ Neurol Sci, 1993;14:317-320.

09. Dahm P, Nitescu P, Appelgren L et al - Efficacy and technical complications of long-term continuous intraspinal infusions of opioid and/or bupivacaine in refractory nonmalignant pain: a comparison between the epidural and the intrathecal approach with externalized or implanted catheters and infusion pumps. Clin J Pain, 1998;14:4-16.

10. Ferrante FM, Paggioli J, Cherukuri S et al - The analgesic response to intravenous lidocaine in the treatment of neuropathic pain. Reg Anesth, 1996;82:91-97.

11. Krause KH, Demaurex N, Jaconi $\mathrm{M}$ et al - Ion channels and receptor-mediated $\mathrm{Ca} 2+$ influx in neutrophil granulocytes. Blood Cells, 1993;19:165-173.

12. Mikawa K, Maekawa N, Nishina K et al - Effect of lidocaine pretreatment on endotoxin-induced lung injury in rabbits. Anesthesiology, 1994;81:689-699.

13. Schmidt W, Schmidt $H$, Bauer $\mathrm{H}$ et al - Influence of lidocaine on endotoxin-induced leukocyte-endothelial cell adhesion and macromolecular leakage in vivo. Anesthesiology, 1997;87: 617-624.

14. Hollmann MW, Durieux ME - Local anesthetics and the inflammatory response: a new therapeutic indication? Anesthesiology, 2000;93:858-875.

15. Nellgard P, Jonsson A, Bojo L et al - Small-bowel obstruction and the effects of lidocaine, atropine and hexamethonium on inflammation and fluid losses. Acta Anaesthesiol Scand, 1996;40: 287-292.

16. Rimback G, Cassut J, Faxen A et al - Effects of intra-abdominal bupivacaine instillation on postoperative colonic motility. Gut, 1986;27:170-175

17. Martinsson T, Oda T, Fernivk E et al - Ropivacaine inhibits leukocyte rolling, adhesion and CD11b/CD18 expression. J Pharmacol Exp Ther, 1997;283:59-65.

18. Hattori M, Dohi S, Nozaki M et al - The inhibitory effects of local anesthetics on superoxide generation of neutrophils correlate with their partition coefficients. Anesth Analg, 1997;84:405-412.

19. Wallace MS, Laitan S, Licht D et al - Concentration-effect Relations for Intravenous lidocaine Infusions in human volunteers: effects on acute sensory thresholds and capsaicin-evoked hyperpathia. Anesthesiology, 1997;86:1262-1272.

20. Tsai $P$, Buerkle $H$, Huang LT et al - Lidocaine concentrations in plasma and cerebrospinal fluid after systemic bolus administration in humans. Reg Anesth, 1998;87:601-604.

21. Swanton BJ, Shorten G - Anti-inflammatory effects of local anesthetic agents. Int Anesthesiol Clin, 2003:41:1-19.

\section{RESUMEN}

Kraychete DC, Guimarães AC, Carvalho MG, Carvalho EM - Papel de la Lidocaína por Vía Venosa en el Tratamiento del Dolor en la Esclerodermia. Relato de un Caso

JUSTIFICATIVA Y OBJETIVOS: La esclerodermia o esclerosis sistémica progresiva es una enfermedad sistémica del tejido conjuntivo, de causa desconocida, que acostumbra acontecer con microangiopatía, isquemia de extremidades y dolorintenso. El objetivo de este relato es describir un caso del empleo de lidocaína por vía venosa en el tratamiento del dolor en el curso de isquemia y dar énfasis a una posible acción 
antiinflamatoria de los anestésicos locales en los pacientes con esclerodermia.

RELATO DE CASO: Paciente del sexo femenino, 34 anos, auxiliar de enfermera, portadora de esclerodermia hace aproximadamente 8 años, presentaba dolor de elevada intensidad (escala numérica $=10$ ) en los miembros superiores e inferiores, continua, diaria, acompañada de alteraciones tróficas, de color y de temperatura y pequeñas úlceras en las extremidades. La paciente fue sometida a una sesión semanal de lidocaína a $2 \%(400 \mathrm{mg})$ sin vasoconstrictor por vía venosa durante 10 semanas con alivio del dolor, del turgor, de la elasticidad de la piel y de la perfusión periférica.

CONCLUSIONES: El alivio del dolor y de otros síntomas después de la administración de lidocaína por vía venosa sugiere que los anestésicos locales pueden modular la respuesta inflamatoria en varios aprendizajes de la esclerodermia. 